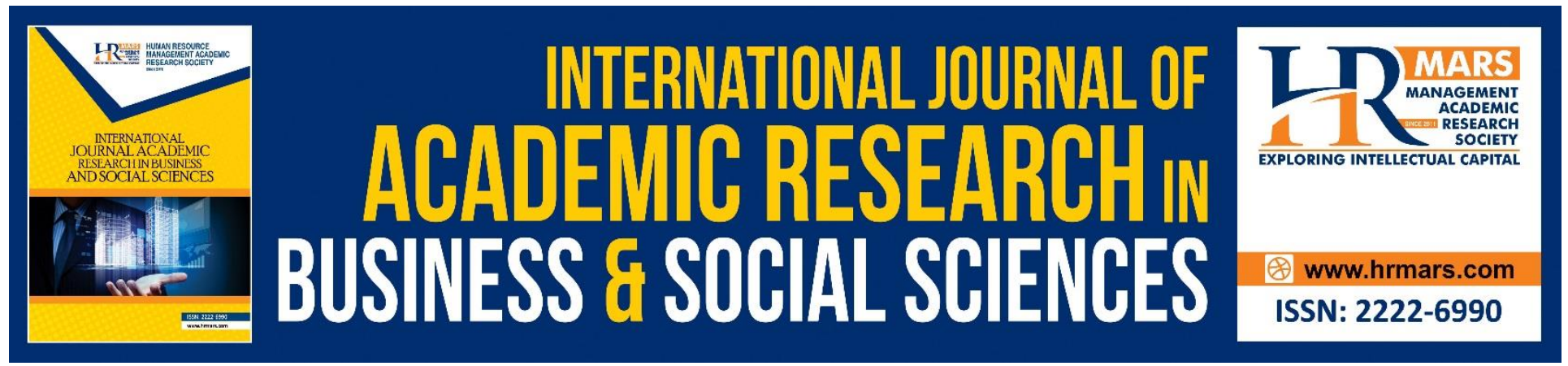

\title{
Assessing Job Performance of Tax Agents via E-Filing System
}

Nurul Hannani Hashim, Nadiah Abd Hamid, Norfadzilah Rashid

To Link this Article: http://dx.doi.org/10.6007/IJARBSS/v8-i11/5196

DOI: $10.6007 /$ IJARBSS/v8-i11/5196

Received: 22 Oct 2018, Revised: 21 Nov 2018, Accepted: 30 Nov 2018

Published Online: 09 Dec 2018

In-Text Citation: (Hashim, Hamid, \& Rashid, 2018)

To Cite this Article: Hashim, N. H., Hamid, N. A., \& Rashid, N. (2018). Assessing Job Performance of Tax Agents via E-Filing System. International Journal of Academic Research in Business and Social Sciences, 8(11), 13691378.

Copyright: (C) 2018 The Author(s)

Published by Human Resource Management Academic Research Society (www.hrmars.com)

This article is published under the Creative Commons Attribution (CC BY 4.0) license. Anyone may reproduce, distribute, translate and create derivative works of this article (for both commercial and non-commercial purposes), subject to full attribution to the original publication and authors. The full terms of this license may be seen at: http://creativecommons.org/licences/by/4.0/legalcode

Vol. 8, No. 11, 2018, Pg. 1369 - 1378

http://hrmars.com/index.php/pages/detail/IJARBSS

JOURNAL HOMEPAGE

Full Terms \& Conditions of access and use can be found at http://hrmars.com/index.php/pages/detail/publication-ethics 


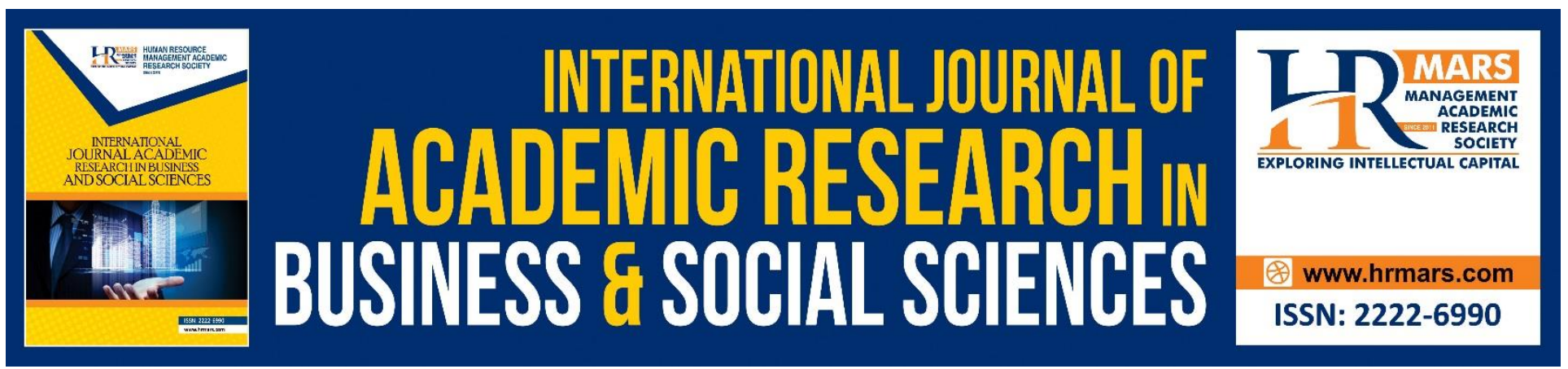

\section{Assessing Job Performance of Tax Agents via E-Filing System}

\section{Nurul Hannani Hashim ${ }^{1}$, Nadiah Abd Hamid², Norfadzilah Rashid ${ }^{3}$}

1,2 Universiti Teknologi Mara, Faculty of Accountancy, 40450, Shah Alam, Malaysia

Faculty of Economics and Management Sciences, Universiti Sultan Zainal Abidin, 21300 Kuala Nerus,

Terengganu, Malaysia

\section{Abstract}

Tax agent plays a vital role in ensuring tax compliance of the taxpayers. The consideration on their job performance is crucial to enhance their clients' tax compliance. Tax agents are highly dependent on the e-filing system in performing their job since they are the frequent system users. Despite of its benefits, there are also setbacks in the e-filing system that impeding and hampering the tax agents' job performance which include functionality, information quality and infrastructure issues. The knowledge of the tax agents is also one of the issues on their job performance via e-filing system. Therefore, this conceptual paper aims to identify factors influencing job performance of tax agents in the tax preparation process via e-filing system. This paper proposes a framework which applied the combination of Information System Success (ISS) Theory and Theory of Planned Behaviour (TPB. The framework is useful to identify the area of improvement for e-filing system which lead to the improvement of tax agents' job performance.

Keywords: Theory of Planned Behavior, System Success Theory, Job Performance

\section{INTRODUCTION}

Tax electronic filing (e-filing) has been introduced in 2004 following to the introduction of SelfAssessment System (SAS) which replaced the old tax system, Official Assessment System (OAS) to promote voluntary tax compliance (Sapiei and Kasipillai, 2014; Singh, 2017). According to McKinsey survey, tax e-filing is one of the most popular e-government application which has been introduced as one of the eight flagships under Vision 2020 (Pawelczyk, Singh, and Nadchatram, 2014) .

The e-filing system was first introduced to the tax agent (Aryati Juliana, Ahmad Zamil, and Ibrahim, 2005). Tax agents rely heavily to the system due to their frequent usage on the e-filing system. The large transaction volumes of the tax agents in handling and engaging with their clients is also the reason of their highly dependency towards the e-filing system (Abdul Aziz and Idris, 2017). 
The high demand for the tax agents in filing the taxpayer's return via e-filing system are probably due to the complexity in the tax laws and regulations as well as several problems in the e-filing system faced by the taxpayers (Bagdad, Noor, Abd Hamid, and Aziz, 2017; Saibon, Nawawi, and Puteh Salin, 2016; Santhanamery and Ramayah, 2012). Tax agents are more experienced in using e-filing as they can use both TAef and ezHasil in filing and submitting their clients' tax return. The usage of e-filing by the tax agents give several benefits to them in which it can shorten the time taken of tax return submission, reducing human errors, reducing postage expenses and paper works and less file storage space is needed (Aryati Juliana et al., 2005).

However, e-filing also has several shortcomings that could affect the tax agents' performance. According to (Starkman, 2012), the e-filing system increase the probability of return-preparer fraud due to no physical signature or fingerprints of tax form and envelopes needed during the tax return submission via e-filing system. Besides, the functionality of e-filing does not give much different to the manual filing as both of these medium are required to prepare the necessary input data and keyin those information into the system before it can automatically perform the tax calculation (Tallaha, Shukor, and Hassan, 2014). The information quality of e-filing problems exist when the system is not in the centralized manners where some of the information needed by the tax agents is not appearing in TAef application. Tax agents also have to face the frequent system downtime and que up in the efiling system especially during peak period (Chen, Jubilado, Capistrano, and Yen, 2015; Chumsombat, 2014; Chandra and Ibrahim, 2015). These shortcomings might impede the overall work processes and hampering the accuracy of data in the tax preparation process. The underlying issues on the job performance of the tax agents are always associated with tax agent's cognitive skills and knowledge, for instance, their capability in obtaining clients' complete and accurate documentations and information (Takril and Sanusi, 2014). Therefore, the knowledge of the tax agents should be considered as one of the factors affecting their job performance using e-filing system. The consideration to improve tax agent performance is detrimental as tax agent can promote the tax compliance to the taxpayers (Abd Hamid, Mat Dangi, Mohd and Md Azali, 2017). Since there is such limited research on these topics, the current study seeks to fill the research gap on factors affecting job performance of tax agents' in preparing the tax returns via e-filling system. Thus, the evaluation of the effect of e-filing usage on the tax agents' job performance is vital to uncover factors that can be improvised by the tax authority to increase the efficient function of the e-filing system.

\section{LITERATURE REVIEW}

This study applies a combination of both Theory of Planned Behaviour (TPB) and Information System Succes (ISS) Theory. There are five elements in TPB which are attiude, subjective norms, perceived behavioural control intention and behavior (Ajzen, 1991). Knowledge has been used to examine its effect role as perceived behavioural control driver on the people behavior (Ajzen, Joyce, Sheikh, and Cote, 2011). Thus, only perceived behavioural control has been chosen in this study as it can measure the behavioural performance directly compared to the attitude and subjective norms. As e-filing is mandated to the tax agents, the intention to use is no longer relevant. ISS has been used 
INTERNATIONAL JOURNAL OF ACADEMIC RESEARCH IN BUSINESS AND SOCIAL SCIENCES Vol. 8, No. 11, Nov, 2018, E-ISSN: 2222-6990 @ 2018 HRMARS

to measure the information system success by introducing its model theory, Delone and Mclean model (Delone and McLean, 1992; DeLone and McLean, 2003). There are six dimensions altogether in this model which are system quality, information quality, infrastructure, intention to use, user satisfaction and net benefits. Same with TPB, intention to use dimension in ISS has been excluded as it is no longer relevant in this study. This study also excludes the user satisfaction as this dimension is not within the scope of study.

Performance is achieved when a set of predetermined standards, such as, accuracy, timeliness, completeness and adhering to certain regulations to perform a certain tasks are fulfilled (Afshan, Sobia, Kamran, and Nasir, 2012; Ali-Hassan, Nevo, and Wade, 2015). Job performance is being considerable enough when an individual can meet the expectations of the organizations or the persons whose they work with (Alibraheem and Abdul-Jabbar, 2016). In regards to the job performance of the tax agents, they need to fulfill the client's expectation and able to improve the tax compliance of their clients at the same time as to ensure their job performance (Kang, 2018).

Functionality is one of the indicators under system quality (Delone and McLean, 1992; DeLone and McLean, 2003). System functionality must have all the possible required functions by the user, the easiness of retrieving information and all the existing features are functioning well (Askari, Kazempoor, Saedi, Eslamirad, and Lajevardi, 2016; Jr, 2017; Tajul Urus, Molla, and Teoh, 2011). By having the adequacy in system functionality, it can give either direct or indirect positive impact to the job performance (Ali and Younes, 2013). The system will have the adequate functionality when the system users can perform their work tasks and fulfill the certain targets and strategic objectives (Dečman and Klun, 2015). In relation to the functionality and e-filing, prior study has proved that one of the user satisfaction factors in using the system is the functionality (Islam, Muhd Yusuf, Yusoff, and Johari, 2012). As relation to functionality and tax agent's performance, a study shows that due to the extra effort is required to use e-filing system, the tax agents who have fewer clients have more dissatisfaction in using the system (Abdul Aziz and Idris, 2017).

Information quality has been defined as the perceived value of the output produced by the users (Negash, Ryan, and Igbaria, 2003). In order to have the high output value and quality, the report generated by the system should have the precise, accurate, timely, relevant, free from bias, understandable, useful and complete criterion (Beest and Boelens, 2009; DeLone and McLean, 2003; Prakosa, 2018). Several prior studies found that the information quality is detrimental to enhance users' job performance (Sung-Whan Koo, Ji-Eun Lee, and Shin, 2012; Yim and Shin, 2014) and suggesting that e-filing service provider should focus on improving information quality of the system that is believed can ensure the system success (Islam et al., 2012; Lu and Nguyen, 2016; Prakosa, 2018). Information quality has also been seen as a key factor which positively influence the system user performance (Ali and Younes, 2013). Therefore, it is believed that with the good information quality in the e-form, tax agents will have better job performance and highly satisfactory towards efiling when the e-filing system can facilitate them to easily communicate with clients and tax authority (Abdul Aziz and Idris, 2014; Axelsson and Ventura, 2007). 
The system provider should provide infrastructure to support every system introduced as to achieve the system service quality (Abdul Aziz and Idris, 2014; Islam et al., 2012). The assurance and responsiveness of the system can be enjoyed by the system users if the infrastructure is provided (DeLone and McLean, 2003; Weill, Subramani, and Broadbent, 2002). The adequacy of IT infrastructure has been found to give positive impact on the job performance of health care providers towards their patients (Salleh, Zakaria, and Abdullah, 2016). Further it shows that IT infrastructure can directly influence an individual job performance in professional line. There are significant positive relationship between e-filing support services and user satisfaction towards the system(Chen et al., 2015; Islam et al., 2012; Prakosa, 2018) in several prior studies. The job performance of the tax agents is believed to increase if they are satisfied with the system (Abdul Aziz and Idris, 2016).

Knowledge is the main capital to all organizations, especially those are classified as knowledgeintensive firms (Ditillo, 2004). Due to its role as the competitive advantage driver particularly to the consulting firms, it is believed to enhance the job performance (Ahn and Chang, 2004; Dunford, 2000). Tax agents should obtain accounting and tax knowledge, literate in information technology (IT), possess high cognitive skills and ability as to minimize the information asymmetry between the tax agents and clients as well as enhancing the taxpayers' compliance (Coolidge, 2012; Kang, 2018). All of these knowledge are vital to the tax agents while submitting the tax return via e-filing as they need to ensure there is no mistake in data input in the system (Ibrahim, Lamidi, and Alias, 2012; Tallaha et al., 2014). Therefore, the following hypotheses are developed:

$\mathrm{H} 1$ : There is a positive relationship between functionality and job performance of the tax agents in tax preparation process via e-filing system.

$\mathrm{H} 2$ : There is a positive relationship between information quality and job performance of the tax agents in tax preparation process via e-filing system.

$\mathrm{H} 3$ : There is a positive relationship between infrastructure and job performance of the tax agents in tax preparation via e-filing system.

$\mathrm{H} 4$ : There is a positive relationship between knowledge and job performance of the tax agents in tax preparation via e-filing system

\section{RESEARCH FRAMEWORK}

This study proposes a framework based on the combination of two theories, TPB and ISS theory. The idea of this study has come out from two main articles (Ali and Younes, 2013; Salleh et al., 2016) which discussed on the impact of information system on the user and health care provider's performance. This current study has contributed by examining in the e-filing context and the job performance of the tax agents adding one more variable which is knowledge under TPB to the study framework. Figure 1 illustrated the research framework for all the hypotheses developed. 


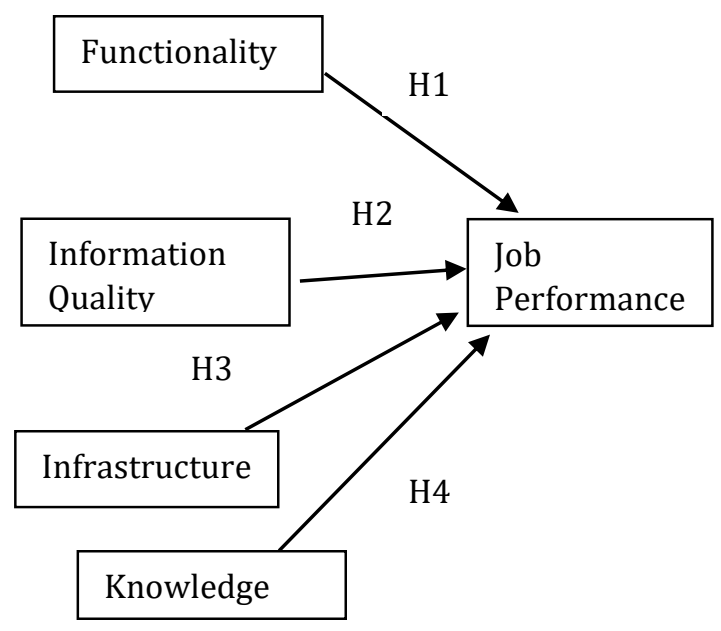

Figure 1: Research Framework

\section{CONCLUSION AND FUTURE RESEARCH}

Previous researches have highlighted several factors impacting the performance of system users. Particularly, this study shed the light on the factors influencing the job performance of the tax agents in the tax preparation process via e-filing system. In this study, it is predicted that many of these factors will positively influence the tax agents' performance. This study has contributed to a new theoretical framework which has the combination of TPB and ISS Theory. Thus, this paper has made further contribution to understand and fill the gap in prior literature on the e-filing and tax agents in Malaysia. By discovering factors that can be improvised by the tax authority, the e-filing system can be more efficient. However, there are some of the factors that might not be covered by this research. Therefore, future researches should be conducted by considering other factors under both theories. Besides, this framework can be applied to all system users, especially those in the accounting field in the future researches.

\section{REFERENCES}

Abd Hamid, N., Mat Dangi, M. D, Mohd, R.R.H. and Md Azali, N., 2017. The effectiveness of GST education providers: Royal Malaysian Customs Department vs Tax agents in Malaysia, Advanced Science Letter, Vol. 8. No. 2: pp $35-45$

Abdul Aziz, S., and Idris, K. M., (2014). Does Design Matter in Tax E-filing Acceptance? Procedia - Social and Behavioral Sciences, 164(August): 451-457. https://doi.org/10.1016/j.sbspro.2014.11.102

Abdul Aziz, S., and Idris, K. M., (2016). E-taxation: The attitude and intention to use technology in Malaysia. International Conference on Accounting Studies (ICAS), (August): 1-4.

Abdul Aziz, S., and Idris, K. M., (2017). The Effect of Volume of Transaction On The Intention Towards Tax E-filing. SHS Web of Conferences, 11003, 0-4. 
INTERNATIONAL JOURNAL OF ACADEMIC RESEARCH IN BUSINESS AND SOCIAL SCIENCES

Vol. 8, No. 11, Nov, 2018, E-ISSN: 2222-6990 @ 2018 HRMARS

Afshan, S., Sobia, I., Kamran, A., and Nasir, M., 2012. Impact of training on employee performance: a study of telecommunication sector in Pakistan. Interdisciplinary Journal of Contemporary Research in Business, 4(6): 30-67.

Ahn, J. H., and Chang, S. G, 2004.. Assessing the contribution of knowledge to business performance: The KP3methodology. Decision Support Systems, 36(4): 403-416. https://doi.org/10.1016/S0167-9236(03)00029-0

Ajzen, I., 1991. The theory of planned behavior. Orgnizational Behavior and Human Decision Processes, 50: 179-211. https://doi.org/10.1016/0749-5978(91)90020-T

Ajzen, I., Joyce, N., Sheikh, S., and Cote, N. G., 2011. Knowledge and the prediction of behavior: The role of information accuracy in the theory of planned behavior. Basic and Applied Social Psychology, 33(2): 101-117. https://doi.org/10.1080/01973533.2011.568834

Ali-Hassan, H., Nevo, D., and Wade, M., 2015. Linking dimensions of social media use to job performance: The role of social capital. Journal of Strategic Information Systems, 24(2): 65-89. https://doi.org/10.1016/j.jsis.2015.03.001

Ali, B. M., and Younes, B., 2013. The Impact of Information Systems on User Performance: An Exploratory Study. Journal of Knowledge Management, Economics and Information Technology, III(2): 128-154. $\quad$ Retrieved from http://www.scientificpapers.org/wpcontent/files/1369_THE_IMPACT_OF_INFORMATION_SYSTEMS_ON_USER_PERFORMANCE.pdf

Alibraheem, M. H., and Abdul-Jabbar, H., 2016. Electronic Tax Filing Adoption and its Impact on Tax Employees Performance in Jordan: A Proposed Framework. World Applied Sciences Journal, 34(3): 393-399. https://doi.org/10.5829/idosi.wasj.2016.34.3.15671

Aryati Juliana, S., Ahmad Zamil, A. K., and Ibrahim, I., 2005. Perceptions of Electronic Filing (E-filing) Among Tax Agent in Northern Region of Malaysia. Proceedings of International Conference on E-Commerce 2005 Perception, (February), 1-11.

Askari, M., Kazempoor, M., Saedi, H. R., Eslamirad, A., and Lajevardi, M., 2016. Measuring E-Service Quality from the Customers' Perspective : An Empirical Study on Banking Services. Journal of Marketing and Consumer Research, 24(2016): 57-68.

Axelsson, K., and Ventura, S., 2007. Reaching Communication Quality in Public E-Forms - A Communicative Perspective on E-Form Design. Electronic Government: 342-353. https://doi.org/10.1007/978-3-540-74444-3_29

Bagdad, M. A., Noor, R. M., Abd Hamid, N., and Aziz, R. A., 2017. Factors affecting tax gap: evidence from Tax audit cases. Global Conference on Business and Economics Research. Retrieved from www.econ.upm.edu.my

Beest, F. Van, and Boelens, S., 2009. Quality of Financial Reporting: measuring qualitative 
INTERNATIONAL JOURNAL OF ACADEMIC RESEARCH IN BUSINESS AND SOCIAL SCIENCES

Vol. 8, No. 11, Nov, 2018, E-ISSN: 2222-6990 @ 2018 HRMARS

characteristics. NiCE Working Paper 09-108, (April): 1-41. Retrieved from www.ru.nl/publish/pages/516298/nice_09108.pdf

Chandra, P. and Ibrahim, A., 2015. The Influence of Perceived System Quality and Perceived Information Quality Towards Continuance Intention of Tax E-Filing System in Malaysia. Journal of Technology and Operations Management, 10(2): 52-63.

Chen, J. V., Jubilado, R. J. M., Capistrano, E. P. S., and Yen, D. C., 2015. Factors affecting online tax filing - An application of the IS Success Model and trust theory. Computers in Human Behavior, 43: 251-262. https://doi.org/10.1016/j.chb.2014.11.017

Chumsombat, N., 2014. Factors Influencing User Satisfaction of E-tax filing in Thailand. 2014 IEEE 11th International Conference on E-Business Engineering. https://doi.org/10.1109/ICEBE.2014.23

Coolidge, J., 2012. Findings of Tax Compliance Cost Surveys in Developing Countries. E-Journal of Tax Research, 10(1): 250-279.

Dečman, M., and Klun, M., 2015. The Impact of Information Systems on Taxation: A Case of Users' Experience With an e-Recovery Information System. The Electronic Journal of E-Government, 13(2): 110-121.

Delone, W. H., and McLean, E. R., 1992. Information systems success: The quest for the dependent variable. Information Systems Research, 3(1): 60-95. https://doi.org/10.1287/isre.3.1.60

DeLone, W. H., and McLean, E. R., 2003. The DeLone and McLean model of information systems success: A ten-year update. Journal of Management Information Systems, 19(4): 9-30. https://doi.org/10.1080/07421222.2003.11045748

Ditillo, A., 2004. Dealing with uncertainty in knowledge-intensive firms: The role of management control systems as knowledge integration mechanisms. Accounting, Organizations and Society, 29(3-4), 401-421. https://doi.org/10.1016/j.aos.2003.12.001

Dunford, R., 2000. Key Challenges in the Search for the Effective Management of Knowledge in Management Consulting Firms. Academy of Management Proceedings, 2000(1): A1-A6. https://doi.org/10.5465/APBPP.2000.5535074

Ibrahim, I., Lamidi, W., and Alias, M., 2017. Perceived Usefulness and the Acceptance of Tax E-Filing System : Malaysia and Nigeria Cases. 4th International Conference on E-Commerce.

Inland Revenue Board of Malaysia., 2015. Inland Revenue Board of Malaysia.

Islam, M. A., Muhd Yusuf, D. H., Yusoff, W. S., and Johari, A. N., 2012. Factors affecting user satisfaction in the Malaysian income tax e-filing system. African Journal of Business Management, 6(21): 6447-6455. https://doi.org/10.5897/AJBM11.1689

Jr, R. A. C., 2017. Computer Aided Reading and Pronunciation Practice System for Elementary Level : 
INTERNATIONAL JOURNAL OF ACADEMIC RESEARCH IN BUSINESS AND SOCIAL SCIENCES Vol. 8, No. 11, Nov, 2018, E-ISSN: 2222-6990 (C) 2018 HRMARS

Development and Usability: 17-19.

Kang, M, 2018. Tax Practitioner Compliance. Taxes and Taxation Trends. https://doi.org/10.5772/intechopen.74216

Lu, N. L., and Nguyen, V. T., 2016. Online Tax Filing-E-Government Service Adoption Case of Vietnam. Modern Economy, 7(12): 1498-1504. https://doi.org/10.4236/me.2016.712135

Negash, S., Ryan, T., and Igbaria, M., 2003. Quality and effectiveness in Web-based customer support systems. Information and Management, 40(8): 757-768. https://doi.org/10.1016/S03787206(02)00101-5

Pawelczyk, K., Singh, K. K. K., and Nadchatram, I., 2014. Exploring the Digital Landscape. Kuala Lumpur.

Prakosa, F., 2018. Quality and Effectiveness in Electronic Tax Filling: A Study of Tax-Payer Satisfaction. International Journal of Technology and Business: 98-104.

Saibon, N.A.., Nawawi, A., and Puteh Salin, A.S.A., 2016. E-filing Acceptance by the Individual Taxpayers - A Preliminary Analysis. Journal of Administrative Science, 13(2): 1-14.

Salleh, M. I. M., Zakaria, N., and Abdullah, R., 2016. The Influence of System Quality Characteristics on Health Care Provider's Performance: Empirical Evidence from Malaysia. Journal of Infection and Public Health, (9): 698-707.

Santhanamery, T., and Ramayah, T., 2012. Continued Usage Intention of E-Filing System in Malaysia: The Role of Optimism Bias. Procedia - Social and Behavioral Sciences, 65(ICIBSoS): 397-403. https://doi.org/10.1016/j.sbspro.2012.11.140

Sapiei, N.S., and Kasipillai, J., 2014. Tax Agents Perceptions of the Corporate Taxpayers ' Compliance Costs under the Self-assessment System. International Journal of Business and Management, II(3:, 92-109.

Singh, H., 2017, August 22. IRB Pushing for Taxpayers' Voluntary Compliance. The Malaysian Reserve, p. $24 . \quad$ Retrieved from http://lampiran1.hasil.gov.my/pdf/pdfam/9.IRB_Pushing_for_Taxpayers_Voluntary_Complianc e.pdf

Starkman, J., 2012. The case against efiling. https://doi.org/10.1136/bmj.314.7079.503

Sung-Whan Koo, Ji-Eun Lee, and Shin, M., 2012. The Effect of Mobile Service Quality Factors on the User Satisfaction : Focused on Usage and Job Characteristics. Journal of the Korea Society of IT Services, 11(2): 1-17.

Takril, N. F. B., and Sanusi, S. W. S. A., 2014. An Exploratory Study of Malaysian Tax Practitioners' Perception on the Practice of Aggressive Tax Avoidance. Synergizing Knowledge on Management 
INTERNATIONAL JOURNAL OF ACADEMIC RESEARCH IN BUSINESS AND SOCIAL SCIENCES

Vol. 8, No. 11, Nov, 2018, E-ISSN: 2222-6990 (C) 2018 HRMARS

and Muamalah, (May): 26-27.

Tajul Urus, S., Molla, A., and Teoh, S. Y., 2011. Living with ERP : A Sand Clock Model of End User Problems. Australiasian (ACIS) 2011 Proceedings, 11.

Tallaha, A. M., Shukor, Z. A., and Hassan, N. S. A., 2014. Factors influencing e-filing usage among Malaysian taxpayers: Does tax knowledge matters? Jurnal Pengurusan, 40: 91-101. https://doi.org/10.17576/pengurusan-2014-40-08

Weill, P., Subramani, M., and Broadbent, M., 2002. Building IT Infrastructure for Strategic Agility. MIT Sloan Management Review, (January 2003): 57-66. https://doi.org/10.2139/ssrn.317307

Yim, S., and Shin, M., 2014. Effects of System Quality and Information Quality on the Use and Job Performance of an Enterprise Mobility Solution for a Mobile Office with a Consideration of Task Mobility and Task Interdependence as Control Variables. Asia Pacific Journal of Information Systems, 24(2): 115-140. https://doi.org/10.14329/apjis.2014.24.2.115 